\title{
IL15 Gene
}

National Cancer Institute

\section{Source}

National Cancer Institute. IL15 Gene. NCI Thesaurus. Code C28604.

This gene is involved in the regulation of memory $T$ cells and cytokine production. 